Article

\title{
The Effect of Using Natural or Biotic Dietary Supplements in Poultry Nutrition on the Effectiveness of Meat Production
}

\author{
Nikola Puvača ${ }^{1, * \mathbb{D}}$, Ivana Brkić ${ }^{2}$, Miralem Jahić ${ }^{1}$, Svetlana Roljević Nikolić ${ }^{3}$, \\ Gordana Radović ${ }^{4}$, Dragan Ivanišević ${ }^{1}$, Milorad Đokić ${ }^{5}$, Dragana Bošković ${ }^{1}$, Dragan Ilić ${ }^{2}$, \\ Sandra Brkanlić ${ }^{2}$ and Radivoj Prodanović ${ }^{1}$
}

1 Department of Engineering Management in Biotechnology, Faculty of Economics and Engineering Management in Novi Sad, University Business Academy in Novi Sad, Cvećarska 2, 21000 Novi Sad, Serbia; jahic.miralem@fimek.edu.rs (M.J.); dragan.ivanisevic@fimek.edu.rs (D.I.); pgboskovic@gmail.com (D.B.); rprodanovic@fimek.edu.rs (R.P.)

2 Department of Business Economics and Finance, Faculty of Economics and Engineering Management in Novi Sad, University Business Academy in Novi Sad, Cvećarska 2, 21000 Novi Sad, Serbia; ivana.j.milosevic@fimek.edu.rs (I.B.); dragan.ilic@fimek.edu.rs (D.I.); sandrab@fimek.edu.rs (S.B.)

3 Institute of Agricultural Economics Belgrade, Volgina 15, 11060 Belgrade, Serbia; svetlana_r@iep.bg.ac.rs

4 Dnevnik-Poljoprivrednik AD Novi Sad, Bulevar Oslobođenja 81, 21000 Novi Sad, Serbia; gordana.radovic09@gmail.com

5 Faculty of Biofarming Bačka Topola, University Megatrend, Bulevar maršala Tolbuhina 8, 11070 Novi Beograd, Serbia; milorad59@yahoo.com

* Correspondence: nikola.puvaca@fimek.edu.rs; Tel.: +381-65-219-1284

Received: 11 May 2020; Accepted: 22 May 2020; Published: 26 May 2020

check for updates

\begin{abstract}
The goal of the research was to investigate the effect of dietary natural or biotic additives such as garlic, black pepper, and chili pepper powder in poultry nutrition on sustainable and economic efficiency of this type of production. A total of eight dietary treatments with 1200 broiler chickens of hybrid line Hubbard were formed, with four replicates. During the experimental period, chickens were fed with three period mixtures diets of different average costs: Starter compound mixture two weeks $(0.38 € / \mathrm{kg}$ in all treatments), grower compound mixture next three weeks $(0.36,0.38,0.40,0.41$, $0.46,0.39,0.42$, and $0.39 € / \mathrm{kg}$, respectively), and finisher compound mixture for the final week (0.34, $0.36,0.38,0.39,0.44,0.37,0.40$, and $0.37 € / \mathrm{kg}$, respectively). The experiment lasted a total of 42 days. Upon finishing the experiment, results have shown statistically significant $(\mathrm{p}<0.05)$ differences regarding the European broiler index (EBI) as one of the indicators of economic efficacy. The EBI was lowest in the control treatment (220.4) and significantly higher in experimental treatments (298.6), respectively. In cost, a calculation included the cost of feed and used natural or biotic supplements in chicken nutrition. The findings of the study of economic efficiency revealed that the cost per treatment rises depends on the natural additive used. Economic efficiency analysis showed that the most economical natural additive with the lowest cost is garlic $(0.68 € / \mathrm{kg})$, while the most uneconomical is treatment with black pepper with the highest cost of body weight gain $(0.82 € / \mathrm{kg})$. This higher cost of the gained meat is minimal as a consequence of a much healthier and more nutritious food meant for human use, which often promotes sustainable aspects, compared to conventional and industrialized poultry production.
\end{abstract}

Keywords: meat; organic; biotic; natural; agriculture; poultry; economic efficiency; costs 


\section{Introduction}

Animal nutrition plays an especially important role and feed accounts for up to almost eighty percent of total livestock production costs [1]. Each segment in the process has to have a strong goal on how feed quality can be optimized and feed cost controlled in animal production, and work towards achieving these goals daily [2]. The constant increase of feed ingredient costs, particularly major protein feedstuff such as soybean meal, forces producers to refocus how they will use their resources in feeding to increase economic efficiency to make the extra mile more efficient to convert feed protein into high-quality meat products [3,4]. Another problem comes with the prohibition of antibiotics used in livestock growth promotion due to antimicrobial tolerance development [5], therefore the natural alternative for growth promoting in animal nutrition has been required [6]. When excluded from daily nutrition, antibiotics as growth promoters were not replaced with natural alternatives, which has led to numerous problems in production, such as the increase of feed conversion ratio (FCR) and increased incidence and outbreaks of animal diseases [7-9]. There are now numerous alternatives to antibiotics as growth stimulators [10]. In addition to herbs' and spices' essential role in human nutrition, these natural and biotic additives have been used to improve the health and general wellbeing of animals as well, especially in poultry [11-16]. Biotic additives originate from plants that have been used in animal nutrition to improve performance. The exact mode of action of these biotic additives and their derivates is not yet quite clear. Some studies have shown that this additive contributes to the balance of gastrointestinal microbiota through controlling pathogens [17]. A significant number of bioactive substances present in essential oils leads to a reduction of the Clostridium sp. population in the digestive tract and poultry feces $[18,19]$. In industrial poultry production, many different forms of oregano [20], rosemary [21], sage [22], thyme [23], garlic [24], black pepper [3], and chili [25] have been used separately or in a mixture as feed additives [26-28]. In recent years, the natural additive cost has been decreased mainly because of a large number of competitors present in the market [29]; however, it is expected that the cost of protein and energy feedstuffs will remain high and continue increasing in the long term [30]. There is no question that extra efforts will be necessary to optimize the use of feed and natural additives to promote animal growth in the long term [11]. The European industry is now under tremendous pressure to reduce the usage of antibiotics and is faced with a growing desire from customers for good quality and safe products and meat [3] and eggs [5,31,32] from sustainable and welfare production systems. Such problems include the return of each component in the supply chain in terms of feeding and management while remaining centered on customer demand [33,34]. This complicated condition cannot be fixed easily. The productivity and economic and social dimensions of a method of production are major problems [35,36]. In the European economy, though, the biggest challenge to development is the failure to produce economic outcomes, so the producers need solutions for long-term survival [37]. There is no single change that can optimize dietary performance; only multi-level changes can be the possible solution [6]. It is therefore necessary to re-evaluate and fine-tune established nutritional concepts.

The goal of the research was to investigate the effect of dietary natural or biotic additives such as garlic, black pepper, and chili pepper powder in poultry nutrition on the sustainable and economic efficiency of this type of production.

\section{Materials and Methods}

Ethical Approval: Biological experiment was performed following the EU legislation and principle of the Three Rs within Directive 2010/63/EU.

Animals and Experimental Design: At the start of the trial, in four iterations, eight treatments on a total of 1200 chickens with 150 one-day-old chickens per treatment were formed. For the nutrition of chicks, three mixtures were used. Starter, grower, and finisher compound feed mixtures, respectively. In the first two weeks, chicks were fed with a starter compound mixture of an average cost of $0.38 € / \mathrm{kg}$. Over the next three weeks, chickens were fed with grower compound mixtures of average cost of $0.36,0.38,0.40,0.41,0.46,0.39,0.42$, and $0.39 € / \mathrm{kg}$, respectively. Afterwards, in the last week of 
the experiment, chickens were fed with finisher compound mixtures of average cost of $0.34,0.36$, $0.38,0.39,0.44,0.37,0.40$, and $0.37 € / \mathrm{kg}$, respectively. The experimental design of the experiment is given in Figure 1. Chicks were provided with fed and water ad libitum during the whole trial period, while microclimate conditions were regularly monitored and maintained following specific hybrid requirements provided by the chickens' producer. Chickens were reared on the floor wheat straw bedding system. To monitoring the productive performance of chickens, body weight and feed consumption were recorded every week.

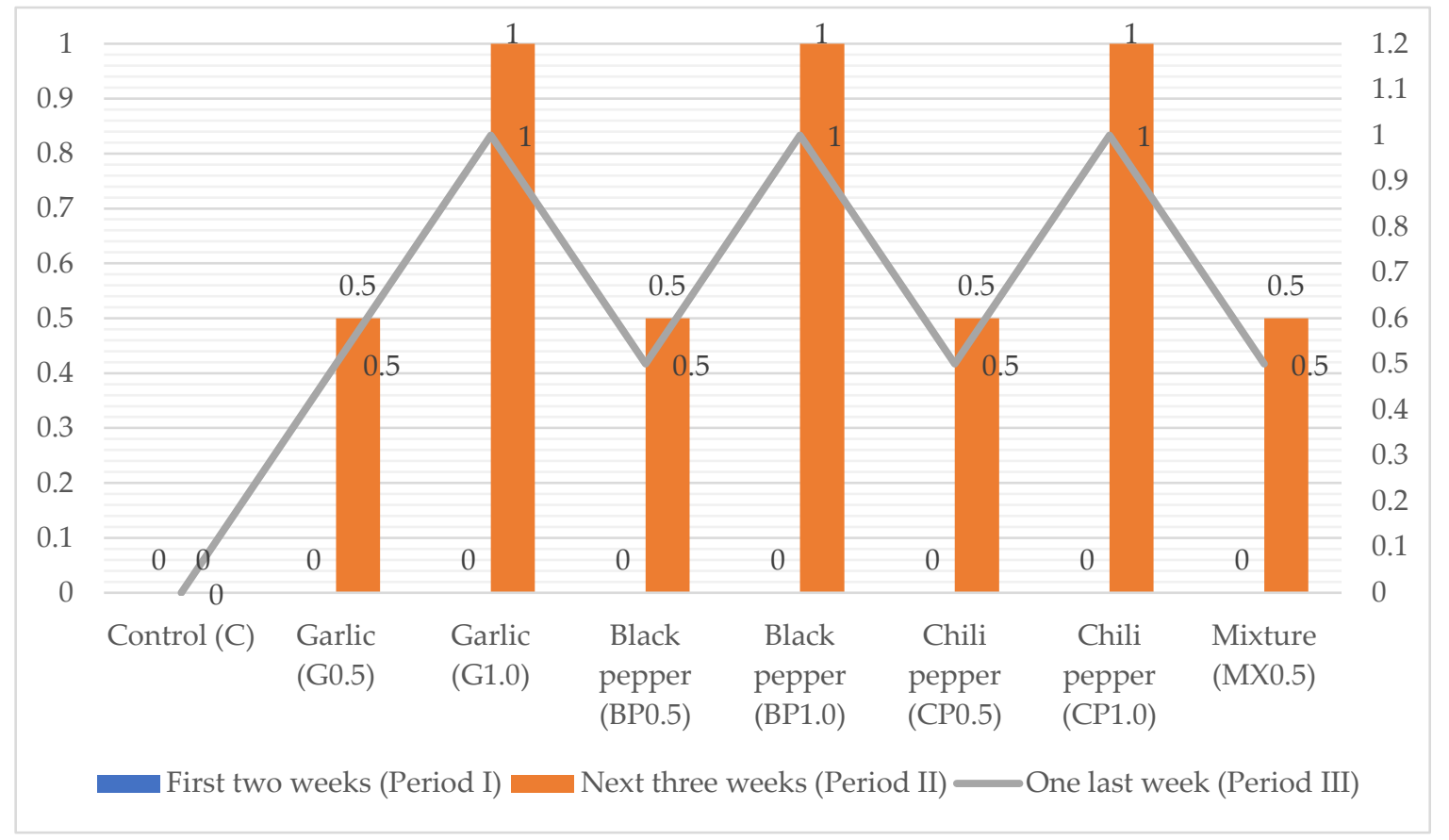

Figure 1. Experimental design with dietary natural or biotic additives, \%. Period I-from 1st to 14th day of trial; Period II-from 15th to 35th day of trial; Period III-from 36th to 42nd day of trial; 0.5 - concentration of natural feed additive $0.5 \%$; 1.0 - concentration of natural feed additive $1 \%$; C-control treatment without additives; G-garlic powder treatment; BP-black pepper powder treatment; $\mathrm{CP}$ — chili pepper powder treatment; $\mathrm{MX}$ - mixture treatment (G:BP:CP-1:1:1).

Economic and Sustainability Assessment: The economic criteria were focused on the cost of production during the trial. At the end of the 42 days of fattening, the cost of production was determined by the final body mass of the chickens. Cost or divisions of output were calculated based on 1200 broiler chickens, overall. The estimation of economic indicators of production for all experimental treatments by feed periods, as well as for the entire fattening period of chickens, was calculated based on the cost of a kilogram of chicken (CKC), economic efficiency index (EEI), and cost index (CI), and according to the following mathematical Equations (1)-(3):

$$
\begin{aligned}
\mathrm{CKC}(€ / \mathrm{kg}) & =\frac{\text { cost of } 1 \mathrm{~kg} \text { of feed }(€) \times \text { chicken feed consumption }(\mathrm{kg})}{\text { chicken body weight gain }(\mathrm{kg})} \\
\mathrm{EEI}(\%) & =\frac{\text { the lowest } \cos \mathrm{t} \text { of } 1 \mathrm{~kg} \text { of body weight gain }(€)}{\text { cost of } 1 \mathrm{~kg} \text { of body weight gain }(€)} \times 100 \\
\mathrm{CI}(\%) & =\frac{\text { cost of } 1 \mathrm{~kg} \text { of body weight gain }(€)}{\text { the lowest cost of } 1 \mathrm{~kg} \text { of body weight gain }(€)} \times 100
\end{aligned}
$$

Statistical Analyses: Data obtained from the trial were analyzed within the statistical software Statistica 13. The data were submitted to analysis of variance (ANOVA) and Fisher's LSD post hoc test 
of significance with Bonferroni correction. The findings were presented as the least square means (LSM) and the standard error $\left(\mathrm{SE}_{\mathrm{LSM}}\right)$. Results were considered statistically significant when $\mathrm{p}<0.05$.

\section{Results and Discussion}

Based on findings obtained, it was observed that natural additives added to the diet of broiler chickens led to statistically significant $(\mathrm{p}<0.05)$ body weight differences (Table 1 ).

Table 1. Least square means of broiler chickens' productive parameters.

\begin{tabular}{ccccccccccc}
\hline & \multicolumn{3}{c}{ BW, kg } & \multicolumn{3}{c}{ FCR, kg/kg } & \multicolumn{3}{c}{ EBI, \% } & M, \% \\
\cline { 2 - 10 } Treatments & \multicolumn{3}{c}{ Period } & \multicolumn{3}{c}{ Period } & & Period & Period \\
\cline { 2 - 11 } & I & II & III & I & II & III & Total & Total & Total \\
\hline C & $0.39^{\mathrm{a}}$ & $1.64^{\mathrm{c}}$ & $2.08^{\mathrm{d}}$ & $1.3^{\mathrm{a}, \mathrm{b}}$ & $1.8^{\mathrm{ab}}$ & $3.0^{\mathrm{a}}$ & $2.1^{\mathrm{a}}$ & $220.4^{\mathrm{g}}$ & $5.1^{\mathrm{a}}$ \\
G0.5 & $0.39^{\mathrm{a}}$ & $1.74^{\mathrm{b}}$ & $2.37^{\mathrm{b}}$ & $1.4^{\mathrm{a}, \mathrm{b}}$ & $1.7^{\mathrm{b}}$ & $2.3^{\mathrm{b}}$ & $1.8^{\mathrm{a}}$ & $295.1^{\mathrm{a}, \mathrm{b}}$ & $3.2^{\mathrm{a}, \mathrm{b}}$ \\
G1.0 & $0.38^{\mathrm{a}}$ & $1.74^{\mathrm{b}}$ & $2.34^{\mathrm{b}, \mathrm{c}}$ & $1.4^{\mathrm{a}, \mathrm{b}}$ & $1.8^{\mathrm{b}}$ & $2.5^{\mathrm{b}}$ & $1.9^{\mathrm{a}}$ & $283.7^{\mathrm{c}, \mathrm{d}}$ & $1.3^{\mathrm{b}, \mathrm{c}}$ \\
BP0.5 & $0.38^{\mathrm{a}}$ & $1.58^{\mathrm{d}}$ & $2.08^{\mathrm{d}}$ & $1.4^{\mathrm{a}, \mathrm{b}}$ & $1.9^{\mathrm{a}}$ & $2.5^{\mathrm{b}}$ & $1.9^{\mathrm{a}}$ & $244.4^{\mathrm{f}}$ & $1.3^{\mathrm{b}, \mathrm{c}}$ \\
BP1.0 & $0.38^{\mathrm{a}}$ & $1.50^{\mathrm{e}}$ & $2.08^{\mathrm{d}}$ & $1.3^{\mathrm{b}}$ & $1.9^{\mathrm{a}, \mathrm{b}}$ & $2.3^{\mathrm{b}}$ & $1.8^{\mathrm{a}}$ & $260.4^{\mathrm{e}}$ & $0.6^{\mathrm{b}, \mathrm{c}}$ \\
CP0.5 & $0.38^{\mathrm{a}}$ & $1.82^{\mathrm{a}}$ & $2.46^{\mathrm{a}}$ & $1.4^{\mathrm{a}}$ & $1.8^{\mathrm{ab}}$ & $2.4^{\mathrm{b}}$ & $1.9^{\mathrm{a}}$ & $298.6^{\mathrm{a}}$ & $2.6^{\mathrm{a}, \mathrm{c}}$ \\
CP1.0 & $0.38^{\mathrm{a}}$ & $1.81^{\mathrm{a}}$ & $2.44^{\mathrm{a}}$ & $1.4^{\mathrm{a}, \mathrm{b}}$ & $1.8^{\mathrm{b}}$ & $2.6^{\mathrm{b}}$ & $1.9^{\mathrm{a}}$ & $288.6^{\mathrm{b}, \mathrm{c}}$ & $2.6^{\mathrm{ac},}$ \\
MX0.5 & $0.38^{\mathrm{a}}$ & $1.72^{\mathrm{b}}$ & $2.30^{\mathrm{c}}$ & $1.4^{\mathrm{a}, \mathrm{b}}$ & $1.8^{\mathrm{b}}$ & $2.6^{\mathrm{b}}$ & $1.9^{\mathrm{a}}$ & $279.6^{\mathrm{d}}$ & $0.0^{\mathrm{c}}$ \\
\hline SE & 3.81 & 12.02 & 23.78 & 0.01 & 0.05 & 0.14 & 0.15 & 2.77 & 0.96 \\
\hline
\end{tabular}

$\mathrm{a}, \mathrm{b}, \mathrm{c}, \overline{\mathrm{d}, \mathrm{e}, \mathrm{f}}$ indicated the difference within a row was significant $(\mathrm{p}<0.05) ; \mathrm{C}$ - control treatment without additives; G0.5 - garlic powder treatment (0.5\%); G1.0 - garlic powder treatment (1.0\%); BP0.5-black pepper powder treatment $(0.5 \%)$; BP1.0-black pepper powder treatment (1.0\%); CP0.5—chili pepper powder treatment (0.5\%); CP1.0-chili pepper powder treatment (1.0\%); MX-mixture treatment (G:BP:CP-1:1:1); BW-body weight; FCR-feed conversion ratio; EBI-European broiler index; M-mortality; SELSM-standard error of least square means.

In the first two weeks of trial, chickens recorded similar body mass without any statistical significance $(p>0.05)$. At the end of the second trial period, a significant $(p<0.05)$ difference in chicken body mass was noticed. Supplementation with natural feed additives in a powder form of chili pepper in the concentration of $0.5 \%(\mathrm{CP} 0.5)$ and $1 \%(\mathrm{CP} 1.0)$ led to significant differences $(\mathrm{p}<0.05)$ in the body mass of chickens compared to control and experimental treatments. At the end of the trial, chickens with the dietary addition of $0.5 \%$ of chili pepper recorded the highest body mass of $2.46 \mathrm{~kg}$, followed by treatment with the addition of $1 \%$ chili pepper $(2.44 \mathrm{~kg})$. Observed differences were statistically significantly $(\mathrm{p}<0.05)$ higher when compared with other treatments. The addition of garlic powder in the concentration of $0.5 \%$ and $1 \%$ led to final body masses $(2.37$ and $2.34 \mathrm{~kg})$ significantly $(\mathrm{p}<0.05)$ higher when compared with final body masses of chickens at treatments C $(2.08 \mathrm{~kg}), \mathrm{BP0} .5(2.08 \mathrm{~kg})$, and BP1.0 $(2.08 \mathrm{~kg})$. Similar observations regarding the usage of natural or biotic dietary supplements in broiler chicken nutrition were noticed when used as natural growth promoters [4,38-50]. During the first two weeks of trial, recorded FCR was 1.3 and $1.4 \mathrm{~kg} / \mathrm{kg}$. In the first two weeks, chickens achieved uniform FCR, as well the body mass, and entered the second trial period without statistically significant differences. Supplementation of all natural or biotic additives reflected a significant increase $(\mathrm{p}<0.05)$ of EBI, when compared to a control treatment $\mathrm{C}$. Control treatment recorded the highest mortality rate and the lowest EBI (Table 1). A mixture of all additives (MX0.5) in the ratio of 1:1:1 in the concentration of $0.5 \%$ had the highest rate of survival $(100 \%)$ during the whole trial period, with recoded EBI of $279.5 \%$, with significant differences $(\mathrm{p}<0.05)$ compared to control treatment and both concentrations of black pepper $(0.5$ and $1 \%)$, respectively. The maximum EBI value observed for treatment CP0.5 was $298.6 \%$, and G0.5 was $295.1 \%$ without any ( $>0.05$ ) discrepancy but significant $(\mathrm{p}<0.05)$ differences with other experimental treatments.

A review of used compound mixtures in the trial, costs, feed consumption, and weight gain of chickens are presented in Table 2. 
Table 2. Cost of feed mixtures in a trial.

\begin{tabular}{|c|c|c|c|c|}
\hline & & Feed Cost, $€ / \mathbf{k g}$ & Feed Consumption, kg & Weight Gain, kg \\
\hline Starter & & 0.38 & 0.44 & 0.345 \\
\hline Grower & $\mathrm{C}$ & 0.36 & 2.25 & 1.255 \\
\hline Finisher & & 0.34 & 1.29 & 0.432 \\
\hline Starter & & 0.38 & 0.48 & 0.347 \\
\hline Grower & G0.5 & 0.38 & 2.30 & 1.353 \\
\hline Finisher & & 0.36 & 1.44 & 0.628 \\
\hline Starter & & 0.38 & 0.48 & 0.344 \\
\hline Grower & G1.0 & 0.40 & 2.43 & 1.350 \\
\hline Finisher & & 0.38 & 1.49 & 0.598 \\
\hline Starter & & 0.38 & 0.47 & 0.341 \\
\hline Grower & BP0.5 & 0.41 & 2.26 & 1.193 \\
\hline Finisher & & 0.39 & 1.24 & 0.498 \\
\hline Starter & & 0.38 & 0.44 & 0.344 \\
\hline Grower & BP1.0 & 0.46 & 2.12 & 1.117 \\
\hline Finisher & & 0.44 & 1.32 & 0.574 \\
\hline Starter & & 0.38 & 0.47 & 0.342 \\
\hline Grower & СР0.5 & 0.39 & 2.57 & 1.427 \\
\hline Finisher & & 0.37 & 1.54 & 0.630 \\
\hline Starter & & 0.38 & 0.47 & 0.343 \\
\hline Grower & CP1.0 & 0.42 & 2.56 & 1.427 \\
\hline Finisher & & 0.40 & 1.63 & 0.630 \\
\hline Starter & & 0.38 & 0.47 & 0.343 \\
\hline Grower & MX0.5 & 0.39 & 2.39 & 1.332 \\
\hline Finisher & & 0.37 & 1.50 & 0.580 \\
\hline
\end{tabular}

The cost of the feed that was used in the trial with chickens presented in Table 2 was formed based on fattening periods (I, II, and III), respectively. The research of Talpaz et al. [51] shows that the ability to determine the optimum density of poultry compound feed that maximizes feeding margins has a strong economic benefit. The same research highlighted that to assess the optimum feed nutrient content, component costs, meat cost in the market, marketing, and availability of biological efficiency of poultry products must be taken into account. The question can be asked, what is the combined effect of meat and feed cost on optimal dietary energy and protein, and do we need to decrease the concentration of energy and protein in the poultry diet when meat or feed cost are increased? Based on our results, the addition of natural additives has beneficial and stimulating effects in broiler chicken nutrition, so the decrease of certain nutrients in the dietary mixture can be considered. The overall cost of the materials and gain in our experiment is shown in Figures 2-4, and Table 3.

After the calculation of chicken feed consumption during the trial and the costs of feed with the natural or biotic supplementation of each treatment, calculation of EEI and CI was performed as well, respectively. It can be seen that the cost of BWG increased with the addition of natural or biotic supplements to the chicken's daily nutrition. 


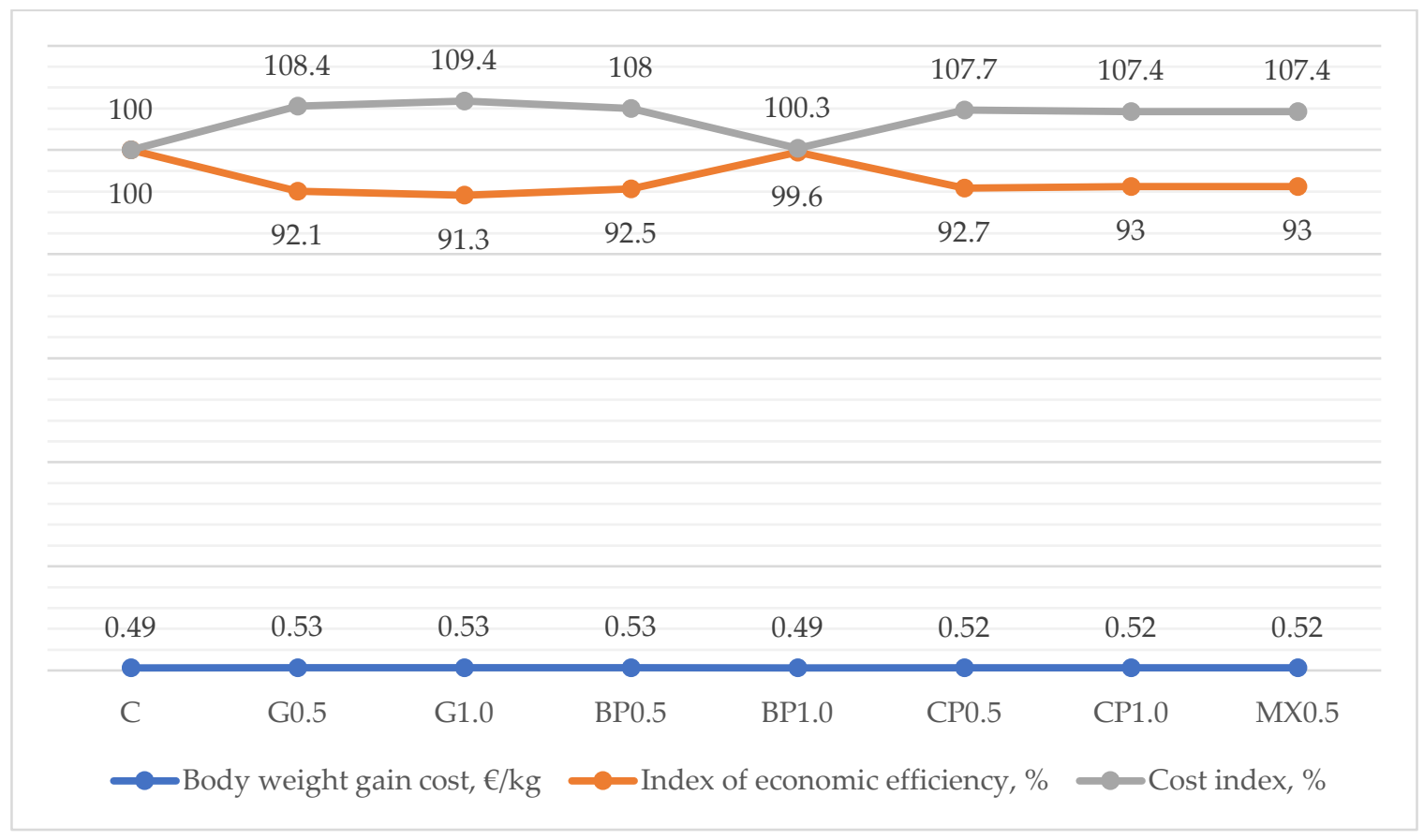

Figure 2. Cost of body weight gain (BWG), economic efficiency index (EEI), and cost index (CI) in period I of the trial.

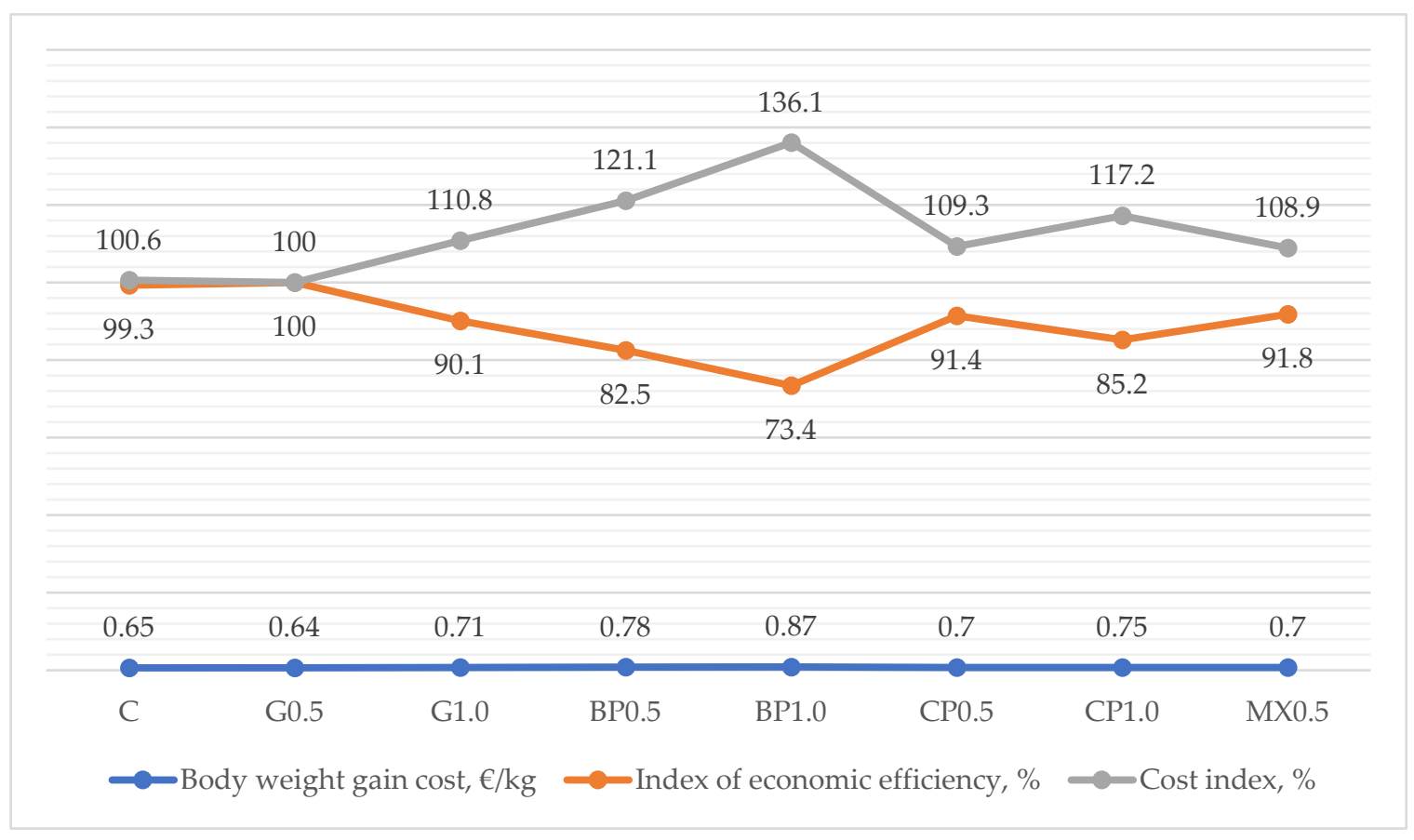

Figure 3. Cost of body weight gain (BWG), economic efficiency index (EEI), and cost index (CI) in period II of the trial. 


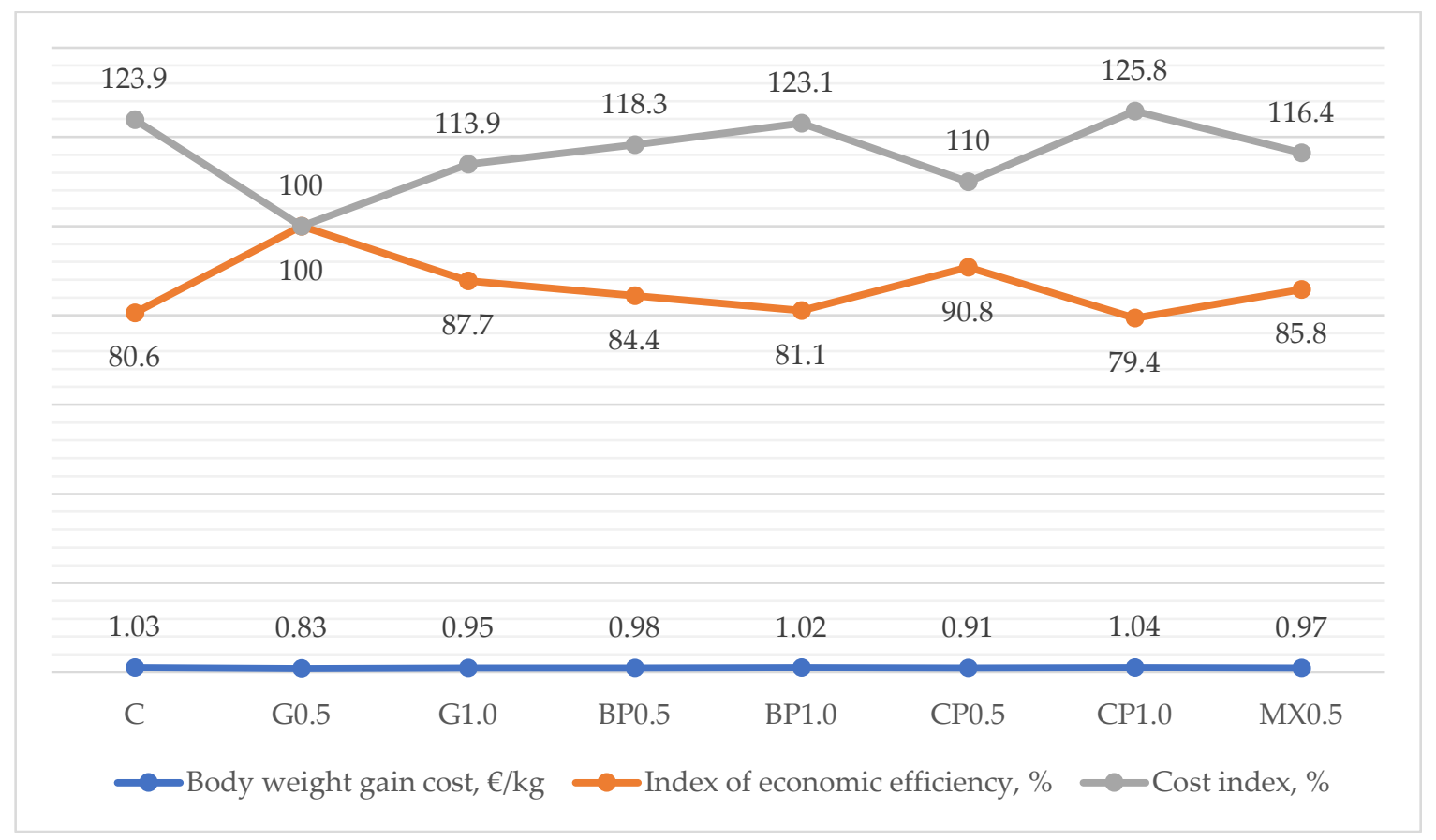

Figure 4. Cost of body weight gain (BWG), economic efficiency index (EEI), and cost index (CI) in period III of the trial.

Table 3. Calculation of cost at the end of the trial.

\begin{tabular}{ccccccccc}
\hline \multirow{2}{*}{ Production Parameters } & \multicolumn{7}{c}{ Experimental Treatments } \\
\cline { 2 - 9 } & C & G0.5 & G1.0 & BP0.5 & BP1.0 & CP0.5 & CP1.0 & MX0.5 \\
\hline Average cost of feed, $€ / \mathrm{kg}$ & 0.36 & 0.37 & 0.39 & 0.40 & 0.43 & 0.38 & 0.40 & 0.38 \\
Average feed consumption, $\mathrm{kg}$ & 3.98 & 4.22 & 4.40 & 3.97 & 3.88 & 4.58 & 4.66 & 4.36 \\
Final body weight gain, $\mathrm{kg}$ & 2.03 & 2.33 & 2.30 & 2.03 & 2.04 & 2.40 & 2.40 & 2.26 \\
Total cost of body weight gain, $€$ & 1.44 & 1.58 & 1.70 & 1.57 & 1.66 & 1.75 & 1.87 & 1.66 \\
Average cost of body weight gain, $€ / \mathrm{kg}$ & 0.71 & 0.68 & 0.74 & 0.77 & 0.82 & 0.73 & 0.78 & 0.74 \\
Cost index, \% & 104.6 & 100.0 & 109.2 & 114.0 & 120.6 & 107.5 & 115.0 & 108.8 \\
\hline
\end{tabular}

As in the first trial period, the second trial period showed similar results. The cost of BWG was the lowest when garlic powder in the concentration of $0.5 \%$ (G0.5) was supplemented to broiler chickens' diet. Supplementation of the black pepper natural additive only at the double concentration of $1 \%$ (BP1.0) showed the highest cost of BWG in the trial, respectively. Identical reflections of CI were observed. Some investigations have shown the reduction in feed cost $/ \mathrm{kg}$ of live BWG of chickens when $1 \%$ of mint leaves was supplemented to a basic diet [52]. Also, the results of other authors regarding the calculation of total cost, revenues, and net profit in the economic study indicated that a mixture of garlic and ginger powder in broiler chicken nutrition showed the highest profitability when compared to diets without biotic supplements.

From the results presented in Table 3, it can be seen that the highest cost of feed per total trial period was recorded in treatment with the addition of $1 \%$ black pepper $(0.43 € / \mathrm{kg})$, while the lowest cost of feed was recorded in the control treatment $(0.36 € / \mathrm{kg})$. The highest recorded average feed consumption for the entire trial period was recorded in chickens with the addition of chili pepper in the concentration of $1 \%(4.66 \mathrm{~kg})$, which indicates the highest stimulative effect on feed consumption. At the end of the trial period, the highest final BWG was recorded in chickens on treatments with both concentrations of chili pepper $(2.40 \mathrm{~kg})$, but with the highest total costs of BWG (1.75 and 1.87 $€)$, respectively. The lowest average cost of BWG for the entire trial period was recorded in the 
treatment with the addition of dietary garlic powder in the concentration of $0.5 \%$, with the lowest $\mathrm{CI}$ of $100 \%$, respectively.

\section{Conclusions}

Supplementation of broiler chickens' daily diet with dietary natural or biotic additives has numerous beneficial effects. Most of these effects are reflected in final products with added value which are functional, healthy, and without any residual antibiotics. Nevertheless, the question can be asked whether that kind of production provides economic benefits to producers, and whether it sustainable.

The results of our research have shown and confirmed that the production of safe and healthy meat can satisfy the demands of the market, which increasingly seeks sustainable and organically produced products, with economic benefit to producers of such types of products.

The addition of garlic powder in a lower concentration for four weeks of chickens fattening is the economical solution and the answer to the previously asked question. The increase in production cost with the addition of garlic powder to the chicken's diet compared to chickens without natural additive supplementation is negligible, keeping in mind the product has improved functional properties intended for human consumption. This kind of obtained product is sustainable and part of organic productions.

Limitations of this kind of study lie in not knowing the exact mechanism and mode of actions of natural and biotic additives, so further research in the field of their mode of action and influence on animals, as well on the quality and safety of obtained products for human consumption, is more than necessary soon.

Author Contributions: Conceptualization, N.P. and I.B.; methodology, N.P.; software, R.P.; validation, M.J., S.R.N., and G.R.; formal analysis, D.B.; investigation, N.P.; resources, D.I. (Dragan Ilić); data curation, D.I. (Dragan Ivanišević); writing—original draft preparation, N.P.; writing—review and editing, I.B.; visualization, M.Đ.; supervision, M.J.; project administration, N.P. and S.B.; funding acquisition, N.P. All authors have read and agreed to the published version of the manuscript.

Funding: This research was funded by the Ministry for Education, Science and Technological Development of the Republic of Serbia, grant number III46012.

Acknowledgments: This research was funded by the Ministry for Education, Science and Technological Development of the Republic of Serbia.

Conflicts of Interest: The authors declare no conflict of interest.

\section{References}

1. Mottet, A.; de Haan, C.; Falcucci, A.; Tempio, G.; Opio, C.; Gerber, P. Livestock: On our plates or eating at our table? A new analysis of the feed/food debate. Glob. Food Secur. 2017, 14, 1-8. [CrossRef]

2. Tullo, E.; Finzi, A.; Guarino, M. Review: Environmental impact of livestock farming and Precision Livestock Farming as a mitigation strategy. Sci. Total Environ. 2019, 650, 2751-2760. [CrossRef]

3. Puvača, N.; Kostadinović, L.; Popović, S.; Lević, J.; Ljubojević, D.; Tufarelli, V.; Jovanović, R.; Tasić, T.; Ikonić, P.; Lukač, D. Proximate composition, cholesterol concentration and lipid oxidation of meat from chickens fed dietary spice addition (Allium sativum, Piper nigrum, Capsicum annuum). Anim. Prod. Sci. 2016, 56, 1920-1927. [CrossRef]

4. Popović, S.; Kostadinović, L.; Đuragić, O.; Aćimović, M.; Čabarkapa, I.; Puvača, N.; Pelić Ljubojević, D. Influence of medicinal plants mixtures (Artemisia absinthium, Thymus vulgaris, Menthae piperitae and Thymus serpyllum) in broilers nutrition on biochemical blood status. J. Agron. Technol. Eng. Manag. 2018, 1, 91-98.

5. Puvača, N.; Lika, E.; Tufarelli, V.; Bursić, V.; Ljubojević Pelić, D.; Nikolova, N.; Petrović, A.; Prodanović, R.; Vuković, G.; Lević, J.; et al. Influence of different tetracycline antimicrobial therapy of Mycoplasma (Mycoplasma synoviae) in laying hens compared to tea tree essential oil on table egg quality and antibiotics residues. Foods 2020, 9, 612. [CrossRef] [PubMed]

6. Puvača, N.; Stanaćev, V.; Glamočić, D.; Lević, J.; Perić, L.; Stanaćev, V.; Milić, D. Beneficial effects of phytoadditives in broiler nutrition. Worlds Poult. Sci. J. 2013, 69, 27-34. [CrossRef] 
7. Alabi, O.; Malik, A.; Ng'ambi, J.; Obaje, P.; Ojo, B. Effect of aqueous moringa oleifera (Lam) leaf extracts on growth performance and carcass characteristics of hubbard broiler chicken. Rev. Bras. Cienc. Avic. 2017, 19, 273-280. [CrossRef]

8. Anadón, A.; Martínez-Larrañaga, M.R.; Ares, I.; Martínez, M.A. Regulatory aspects for the drugs and chemicals used in food-producing animals in the European union. In Veterinary Toxicology; Elsevier: New York, NY, USA, 2018; pp. 103-131.

9. Kostadinović, L.; Lević, J. Effects of phytoadditives in poultry and pigs diseases. J. Agron. Technol. Eng. Manag. 2018, 1, 1-7.

10. Markowiak, P.; Śliżewska, K. The role of probiotics, prebiotics and synbiotics in animal nutrition. Gut. Pathog. 2018, 10, 21. [CrossRef]

11. Puvača, N.; Lika, E.; Cocoli, S.; Shtylla Kika, T.; Bursić, V.; Vuković, G.; Tomaš Simin, M.; Petrović, A.; Cara, M. Use of tea tree essential oil (Melaleuca alternifolia) in laying hen's nutrition on performance and egg fatty acid profile as a promising sustainable organic agricultural tool. Sustainability 2020, 12, 3420. [CrossRef]

12. Čabarkapa, I.; Puvača, N.; Popović, S.; Čolović, D.; Kostadinović, L.; Tatham, E.K.; Lević, J. Aromatic plants and their extracts pharmacokinetics and in vitro/in vivo mechanisms of action. In Feed Additives; Elsevier: London, UK, 2020; pp. 75-88.

13. Popović, S.; Puvača, N.; Kostadinović, L.; Džinić, N.; Bošnjak, J.; Vasiljević, M.; Djuragic, O. Effects of dietary essential oils on productive performance, blood lipid profile, enzyme activity and immunological response of broiler chickens. Eur. Poult. Sci. 2016, 80. [CrossRef]

14. Giannenas, I.; Koidis, A.; Botsoglou, E.; Dotas, V.; Mitsopoulos, I.; Florou-Paneri, P.; Nikolakakis, I. Hen performance and egg quality as affected by dietary oregano essential oil and alpha-tocopheryl acetate supplementation. Int. J. Poult. Sci. 2005, 4, 449-454. [CrossRef]

15. Giannenas, I.; Bonos, E.; Skoufos, I.; Tzora, A.; Stylianaki, I.; Lazari, D.; Tsinas, A.; Christaki, E.; Florou-Paneri, P. Effect of herbal feed additives on performance parameters, intestinal microbiota, intestinal morphology and meat lipid oxidation of broiler chickens. Br. Poult. Sci. 2018, 59, 545-553. [CrossRef] [PubMed]

16. Giannenas, I.; Doukas, D.; Karamoutsios, A.; Tzora, A.; Bonos, E.; Skoufos, I.; Tsinas, A.; Christaki, E.; Tontis, D.; Florou-Paneri, P. Effects of Enterococcus faecium, mannan oligosaccharide, benzoic acid and their mixture on growth performance, intestinal microbiota, intestinal morphology and blood lymphocyte subpopulations of fattening pigs. Anim. Feed Sci. Technol. 2016, 220, 159-167. [CrossRef]

17. Hardeland, R.; Pandi-Perumal, S. Melatonin, a potent agent in antioxidative defense: Actions as a natural food constituent, gastrointestinal factor, drug and prodrug. Nutr. Metab. 2005, 2, 22. [CrossRef]

18. Zeng, Z.; Zhang, S.; Wang, H.; Piao, X. Essential oil and aromatic plants as feed additives in non-ruminant nutrition: A review. J. Anim. Sci. Biotechnol. 2015, 6, 7. [CrossRef]

19. Dahiya, J.P.; Wilkie, D.C.; Van Kessel, A.G.; Drew, M.D. Potential strategies for controlling necrotic enteritis in broiler chickens in post-antibiotic era. Anim. Feed Sci. Technol. 2006, 129, 60-88. [CrossRef]

20. Giannenas, I.; Bonos, E.; Christaki, E.; Florou-Paneri, P. Oregano: A Feed Additive with Functional Properties. In Therapeutic Foods; Elsevier: London, UK, 2018; pp. 179-208.

21. Yesilbag, D.; Eren, M.; Agel, H.; Kovanlikaya, A.; Balci, F. Effects of dietary rosemary, rosemary volatile oil and vitamin $\mathrm{E}$ on broiler performance, meat quality and serum SOD activity. Br. Poult. Sci. 2011, 52, 472-482. [CrossRef]

22. Saki, A.A.; Aliarabi, H.; Hosseini Siyar, S.A.; Salari, J.; Hashemi, M. Effect of a phytogenic feed additive on performance, ovarian morphology, serum lipid parameters and egg sensory quality in laying hen. Vet. Res. Forum. 2014, 5, 287-293.

23. Khan, S.A.; McLean, M.K.; Slater, M.R. Concentrated tea tree oil toxicosis in dogs and cats: 443 cases (2002-2012). J. Am. Vet. Med. Assoc. 2014, 244, 95-99. [CrossRef]

24. Puvača, N.; Ljubojević, D.; Kostadinović, L.; Lukač, D.; Lević, J.; Popović, S.; Đuragić, O. Spices and herbs in broilers nutrition: Effects of garlic (Allium sativum L.) on broiler chicken production. Worlds Poult. Sci. J. 2015, 71, 533-538. [CrossRef]

25. Puvača, N.; Ljubojević, D.; Kostadinović, L.; Lević, J.; Nikolova, N.; Miščević, B.; Könyves, T.; Lukač, D.; Popović, S. Spices and herbs in broilers nutrition: Hot red pepper (Capsicum annuum L.) and its mode of action. Worlds Poult. Sci. J. 2015, 71, 683-688. [CrossRef] 
26. Tripathi, D.; Kumar, A.; Mondal, B.C.; Joyti, P. Effect of dietary supplementation of Ajwain, hot red pepper and black pepper on the performance, haemato-biochemical and carcass characteristics of Japanese quail. Indian J. Poult. Sci. 2017, 52, 288. [CrossRef]

27. Brenes, A.; Roura, E. Essential oils in poultry nutrition: Main effects and modes of action. Anim. Feed Sci. Technol. 2010, 158, 1-14. [CrossRef]

28. Franz, C.; Baser, K.; Windisch, W. Essential oils and aromatic plants in animal feeding - a European perspective. A review. Flavour Fragr. J. 2010, 25, 327-340. [CrossRef]

29. Kleer, R.; Piller, F.T. Local manufacturing and structural shifts in competition: Market dynamics of additive manufacturing. Int. J. Prod. Econ. 2019, 216, 23-34. [CrossRef]

30. Pelletier, N.; Klinger, D.H.; Sims, N.A.; Yoshioka, J.-R.; Kittinger, J.N. Nutritional Attributes, Substitutability, Scalability, and Environmental Intensity of an Illustrative Subset of Current and Future Protein Sources for Aquaculture Feeds: Joint Consideration of Potential Synergies and Trade-offs. Environ. Sci. Technol. 2018, 52, 5532-5544. [CrossRef]

31. Spasevski, N.; Puvača, N.; Pezo, L.; Tasić, T.; Vukmirović, Đ.; Banjac, V.; Čolović, R.; Rakita, S.; Kokić, B.; Džinić, N. Optimisation of egg yolk colour using natural colourants. Eur. Poult. Sci. 2018, 82. [CrossRef]

32. Spasevski, N.; Dragojlović, D.; Čolović, D.; Vidosavljević, S.; Peulić, T.; Rakita, S.; Kokić, B. Influence of dietary carrot and paprika on egg physical characteristics and yolk color. Food Feed Res. 2018, 45, 59-66. [CrossRef]

33. Ashour, E.A.; El-Kholy, M.S.; Alagawany, M.; Abd El-Hack, M.E.; Mohamed, L.A.; Taha, A.E.; El Sheikh, A.I.; Laudadio, V.; Tufarelli, V. Effect of Dietary Supplementation with Moringa oleifera Leaves and/or Seeds Powder on Production, Egg Characteristics, Hatchability and Blood Chemistry of Laying Japanese Quails. Sustainability 2020, 12, 2463. [CrossRef]

34. Tufarelli, V.; Casalino, E.; D’Alessandro, A.G.; Laudadio, V. Dietary phenolic compounds: Biochemistry, metabolism and significance in animal and human health. Curr. Drug Metab. 2018, 18. [CrossRef] [PubMed]

35. Kiel, D.; Müller, J.M.; Arnold, C.; Voigt, K.I. Sustainable industrial value creation: Benefits and challenges of industry 4.0. Int. J. Innov. Manag. 2017, 21, 1740015. [CrossRef]

36. Rauch, E.; Dallasega, P.; Matt, D.T. Sustainable production in emerging markets through Distributed Manufacturing Systems (DMS). J. Clean. Prod. 2016, 135, 127-138. [CrossRef]

37. Ghisellini, P.; Cialani, C.; Ulgiati, S. A review on circular economy: The expected transition to a balanced interplay of environmental and economic systems. J. Clean. Prod. 2016, 114, 11-32. [CrossRef]

38. Marcinčák, S.; Klempová, T.; Bartkovský, M.; Marcinčáková, D.; Zdolec, N.; Popelka, P.; Mačanga, J.; Čertík, M. Effect of fungal solid-state fermented product in broiler chicken nutrition on quality and safety of produced breast meat. BioMed Res. Int. 2018, 1-8. [CrossRef]

39. Farahat, M.; Abdallah, F.; Abdel-Hamid, T.; Hernandez-Santana, A. Effect of supplementing broiler chicken diets with green tea extract on the growth performance, lipid profile, antioxidant status and immune response. Br. Poult. Sci. 2016, 1-9. [CrossRef]

40. Christaki, E.; Giannenas, I.; Bonos, E.; Florou-Paneri, P. Innovative uses of aromatic plants as natural supplements in nutrition. In Feed Additives; Elsevier: London, UK, 2020; pp. 19-34.

41. Lipiński, K.; Mazur, M.; Antoszkiewicz, Z.; Purwin, C. Polyphenols in Monogastric Nutrition-A Review. Ann. Anim. Sci. 2017, 17, 41-58. [CrossRef]

42. Bonos, E.; Kasapidou, E.; Kargopoulos, A.; Karampampas, A.; Christaki, E.; Florou-Paneri, P.; Nikolakakis, I. Spirulina as a functional ingredient in broiler chicken diets. S. Afr. J. Anim. Sci. 2016, 46, 94. [CrossRef]

43. Adaszyńska-Skwirzyńska, M.; Szczerbińska, D. Use of essential oils in broiler chicken production-A review. Ann. Anim. Sci. 2017, 17, 317-335. [CrossRef]

44. Zhai, H.; Liu, H.; Wang, S.; Wu, J.; Kluenter, A.-M. Potential of essential oils for poultry and pigs. Anim. Nutr. 2018, 4, 179-186. [CrossRef]

45. Ogbuewu, I.P.; Okoro, V.M.; Mbajiorgu, E.F.; Mbajiorgu, C.A. Beneficial Effects of Garlic in Livestock and Poultry Nutrition: A Review. Agric. Res. 2019, 8, 411-426. [CrossRef]

46. Ogbuewu, I.P.; Okoro, V.M.; Mbajiorgu, C.A. Meta-analysis of the influence of phytobiotic (pepper) supplementation in broiler chicken performance. Trop. Anim. Health Prod. 2020, 52, 17-30. [CrossRef] [PubMed] 
47. Tashla, T.; Puvača, N.; Pelić, D.L.; Prodanović, R.; Bošković, J.; Ivanišević, D.; Jahić, M.; Mahmoud, O.; Giannenas, I.; Lević, J. Dietary medicinal plants enhance the chemical composition and quality of broiler chicken meat. J. Hellenic Vet. Med. Soc. 2019, 70, 1823-1832. [CrossRef]

48. Puvaca, N.; Kostadinovic, L.; Djuragic, O.; Ljubojevic, D.; Miscevic, B.; Könyves, T.; Popovic, S.; Levic, J.; Nikolova, N. Influence of herbal drugs in broiler chicken nutrition on primal carcass cuts quality assessments. Food Feed Res. 2016, 43, 43-49. [CrossRef]

49. Sidhu, N.S.; Singh, U.; Sethi, A.P.S. Growth Performance and Nutrient Utilisation as Affected by Black Pepper or Jaggery Supplementation and Feed Restriction in Broiler Chicken. Indian J. Anim. Nutr. 2018, 35, 191. [CrossRef]

50. Devi, P.C.; Samanta, A.K.; Das, B.; Kalita, G.; Behera, P.S.; Barman, S. Effect of Plant Extracts and Essential Oil Blend as Alternatives to Antibiotic Growth Promoters on Growth Performance, Nutrient Utilization and Carcass Characteristics of Broiler Chicken. Indian J. Anim. Nutr. 2018, 35, 421. [CrossRef]

51. Talpaz, H.; Cohen, M.; Fancher, B.; Halley, J. Applying complex models to poultry production in the future-Economics and biology. Poult. Sci. 2013, 92, 2541-2549. [CrossRef]

52. Khurshid, A.; Banday, M.T.; Adil, S.; Untoo, M.; Afzal, I. Mint Leaves (Mentha piperita) as Herbal Dietary Supplement: Effect on Performance and Economics of Broiler Chicken Production. Pakistan J. Nutr. 2016, 15, 810-815. [CrossRef]

(C) 2020 by the authors. Licensee MDPI, Basel, Switzerland. This article is an open access article distributed under the terms and conditions of the Creative Commons Attribution (CC BY) license (http://creativecommons.org/licenses/by/4.0/). 